\title{
Central venous oxygen saturation as the predictor of the outcome from mechanical ventilation
}

\author{
Imtiaz Ahmad Bhat ${ }^{1}$, Farhana Bashir ${ }^{2}$, Javed lqbal Naqeshbandi ${ }^{3}$, Mohmmad Sadiq Malla ${ }^{4}$ \\ ${ }^{1}$ Senior Resident, ${ }^{2}$ Assistant Professor, ${ }^{3}$ Professor, ${ }^{4}$ Associate Professor, Department of Anesthesiology and Critical \\ Care, Government Medical College, Srinagar, Jammu and Kashmir, India
}

Background: Central venous oxygen saturation is being currently studied and used to guide extubation in patients on ventilator for more than $48 \mathrm{~h}$. Aims and Objectives: The aim of our study was to compare chances of extubation failure after mechanical ventilation using conventional versus central venous oxygen saturation criteria for weaning from long-term mechanical ventilation. Materials and Methods: This prospective clinical study was conducted in the Postgraduate Department of Anaesthesiology and Critical Care, Government Medical College (GMC) Srinagar and was performed in the Surgical Intensive Care Unit at SMHS, an associated hospital of GMC Srinagar. In our study, fifty-two patients were studied out of which 25 patients were extubated by standard extubation criteria and 27 patients were extubated according to ScvO2 criteria and conventional criteria combined together. Results: Using conventional criteria on 25 patients from 52 patients, $56 \%$ had successful weaning while $44 \%$ had failure in weaning. Here, $11 \%$ should be $44 \%$. While adding ScvO2 criteria on 27 of 52 patients, successful weaning was in $81.48 \%$ and failure in $18.52 \%$. With sensitivity of $95.4 \%$, specificity of $100 \%$, positive predictive value of $100 \%$, negative predictive value of $83.3 \%$, and accuracy of $96.3 \%$ with confidence interval of $95 \%$. Conclusion: ScvO2 criteria when added to conventional criteria help the clinician to estimate proper time for extubation and reduce the rates of reintubation.

Key words: Central venous oxygen saturation; Ventilation, Weaning
Access this article online

Website:

http://nepjol.info/index.php/AJMS DOI: 10.3126/ajms.v13i2.40506

E-ISSN: 2091-0576

P-ISSN: $2467-9100$

Copyright (c) 2022 Asian Journal of Medical Sciences

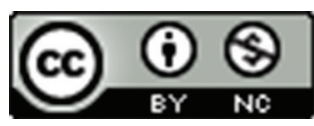

This work is licensed under a Creative Commons Attribution-NonCommercial 4.0 International License.

\section{INTRODUCTION}

The term weaning is defined as the gradual process of decreasing ventilator support. It is estimated that $40 \%$ of the duration of mechanical ventilation is dedicated to the process of weaning. ${ }^{1-4}$

Weaning covers the entire process of disengaging the patient from mechanical support and endotracheal tube, including relevant aspects of terminal care. Weaning procedure usually starts only after the underlying disease process that necessitated mechanical support has significantly improved or is resolved. 5,6 The patient should have an adequate gas exchange, appropriate neurological and muscular status, and stable cardiovascular function. Extubation failure (EF) occurs in approximately $20-32 \%$ of the patients meeting the conventional predictors. ${ }^{7-11}$ The presence of cardiovascular dysfunction can contribute to weaning failure by increasing loads and decreasing neuromuscular capacity.

Although respiratory muscles do not develop fatigue, they perform huge workload. Thus, they rely on efficient oxygen transport by the cardiovascular system. Central venous oxygen saturation (ScvO2) has been successfully used to determine the outcome from mechanical ventilator.

As such in the weaning process (recovery stage from critical illness), measurement of $\mathrm{ScvO} 2$ could potentially be a reliable and convenient tool to warn rapidly about acute changes in the oxygen supply and demand of these patients. 
It has the potential to help the clinician to predict the timely extubation in mechanically ventilated patients. During spontaneous breathing trial (SBT) $\mathrm{ScvO} 2$ could predict EF.

The aim of this study was to compare the chances of EF after mechanical ventilation using conventional versus central venous oxygen saturation criteria for weaning from long-term mechanical ventilation and to establish a more reliable criteria for extubation of long term mechanically ventilated patients.

\section{MATERIALS AND METHODS}

This prospective clinical study was conducted in the Postgraduate Department of Anesthesiology and Critical Care, Government Medical College (GMC) Srinagar and was performed in Surgical Intensive Care Unit at SMHS, an associated hospital of GMC Srinagar after approval by the Institutional Ethical Committee. The informed consent was taken from all the patients or next of kin.

A total of 52 patients were taken in this study. They were mechanically ventilated for more than $48 \mathrm{~h}$ in surgical ICU at Government Medical College Srinagar and were prospectively followed. They were assessed daily for the presence of the following readiness to wean criteria:

Demographic data, routine laboratory investigations (complete blood picture, liver and kidney function tests, and electrolytes), and chest radiographs were collected at admission. Vital signs, mechanical ventilation days, and days in ICU were registered as well.

Enrolled patients were evaluated daily for the presence of weaning criteria. Patients fulfilling these criteria were weaned using two-stage approach: viz evaluation of the indicators of extubation outcome followed by SBT for $30 \mathrm{~min}$.

After patients were assessed for readiness to wean, central venous sample was taken at $1 \mathrm{~min}$ of putting patients on $\mathrm{T}$-piece trial. Arterial sample from radial artery was also collected simultaneously as a part of conventional management.

Sampling of ScvO2 was carried out using catheter threaded through internal jugular vein into the right atrium, which was already in situ during the course of ICU stay.

Patients who successfully tolerated the trial were extubated and then observed in the next $48 \mathrm{~h}$ for the presence of any adverse events and respiratory failure.

Failure of extubation was meant that there was a need to re-intubate the patient within 2 days of the extubation process.
Measurements of hemodynamics (blood pressure, heart rate, and respiratory rate) and $\mathrm{ScvO} 2$ was registered at $1^{\text {st }}$ min of SBT. Patients were put on T-piece and observed for $30 \mathrm{~min}$ and, at $30^{\text {th }}$ min again the conventional criteria and central venous sample was taken.

After observing the patients during the 30 -min period and re-checking the parameters, all the preparations were made for the reintubation. Equipment and drugs were kept ready, proper oral suctioning was done and supplemental oxygen source including non-invasive ventilation device was kept ready. After checking requisite parameters again, patients were extubated and reassured. Supplemental oxygen was given by weaning devices. Some patients needed NIV during weaning period, repeat blood gas sampling was taken at 15 and $30 \mathrm{~min}$. Patients were observed for $48 \mathrm{~h}$ for any signs of respiratory distress, fall in GCS, fall in oxygen saturation, or increase in work of breathing. Conventional relevant lab investigations were also checked and repeated during that 48 -h period as per ICU protocol.

\section{Statistical analysis}

To perform different analysis within the study we used version 22.0 of the statistical package for the social sciences (SPSS) for windows (SPSS Inc., Chicago, Illinois USA). Descriptive data are demonstrated as percentage or mean \pm SD. $\chi^{2}$ and Fisher's exact tests were utilized for the analysis of categorical variables, as appropriate. Mean differences between the investigated variables were assessed by independent $t$-test or Mann-Whitney $U$-test according to the normality of the data. For all tests, any probability value $(<0.05)$ was described as the statistically significant. Same t of study has been done before by Samiha $\mathrm{S}$ Ashmawi et al., ${ }^{12}$ which included 50 patients with the aim of central venous oxygen saturation as a predictor of failure of weaning from mechanical ventilation.

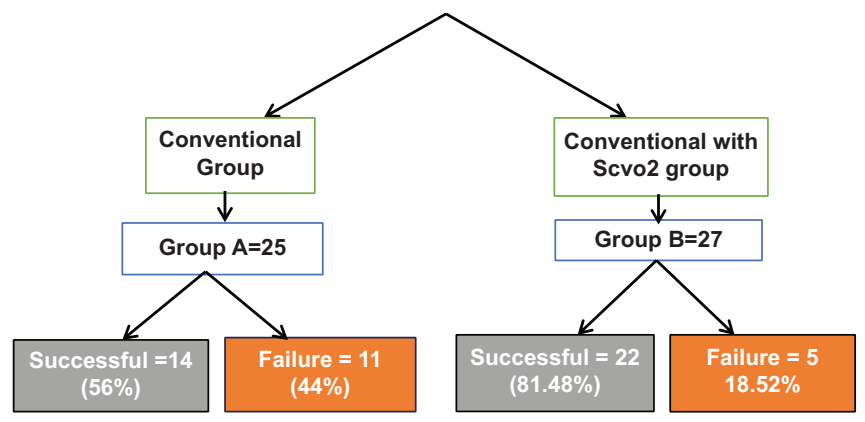

Here in Group B failure box $18.52 \%$ should be within bracket. Like Failure $=5(18.52 \%)$

\section{RESULTS}

In our study, we evaluated 52 patients who were mechanically ventilated for more than $48 \mathrm{~h}$ and compared 
EF in these patients using conventional verses central venous oxygen saturation criteria for weaning from mechanical ventilation. Demographic parameters such as age and gender were compared between two groups and found statistically insignificant $(\mathrm{P}<0.05)$ as shown in Tables 1 and 2 .

Table 1 shows the age distribution of patients in groups $A$ and $\mathrm{B}$. The mean difference of age in the two groups was found to be statistically insignificant.

Table 2 shows the gender distribution of patients in groups $\mathrm{A}$ and B.The difference between the two groups was found to be statistically insignificant.

The difference in ventilation days between two groups was found to be statistically insignificant $(\mathrm{P}<0.05)$ as shown in Table 3.

The difference in hemodynamic parameters and respiratory rate between the two groups was found statistically insignificant as depicted in Table 4.

The difference in ABG parameters between the two groups at I min time after SBT was found to be statistically insignificant as shown in Table 5.

\begin{tabular}{|c|c|c|c|c|c|}
\hline \multirow{2}{*}{$\begin{array}{l}\text { Age } \\
\text { (Years) }\end{array}$} & \multicolumn{2}{|c|}{ Group A } & \multicolumn{2}{|c|}{ Group B } & \multirow[t]{2}{*}{ P-value } \\
\hline & No. & \%age & No. & \%age & \\
\hline $20-29$ & 8 & 32 & 8 & 29.6 & 0.652 \\
\hline 30-39 & 7 & 28 & 6 & 22.2 & \\
\hline $40-49$ & 2 & 8 & 3 & 11.1 & \\
\hline $50-59$ & 3 & 12 & 4 & 14.8 & \\
\hline$\geq 60$ & 5 & 20 & 6 & 22.2 & \\
\hline Total & 25 & 100 & 27 & 100 & \\
\hline $\begin{array}{l}\text { Mean } \pm S D \\
\text { (Range) }\end{array}$ & \multicolumn{2}{|c|}{$\begin{array}{c}40.9 \pm 17.02 \\
(20-70)\end{array}$} & \multicolumn{2}{|c|}{$\begin{array}{c}43.1 \pm 15.96 \\
(22-70)\end{array}$} & \\
\hline
\end{tabular}

\begin{tabular}{lcccccc}
$\begin{array}{l}\text { Table 2: Gender distribution of study patients in } \\
\text { two groups }\end{array}$ \\
\cline { 2 - 3 } Gender & \multicolumn{2}{c}{ Group A } & & \multicolumn{2}{c}{ Group B } & P-value \\
\cline { 2 - 3 } & No. & \%age & & No. & \%age & \\
\hline Male & 11 & 44 & & 17 & 63.0 & 0.171 \\
Female & 14 & 56 & & 10 & 37.0 & \\
Total & 25 & 100 & & 27 & 100 & \\
\hline
\end{tabular}

Table 3: Ventilator duration (days) of study
patients in two groups
\begin{tabular}{lccccc} 
Group & N & Mean & SD & Range & P-value \\
\hline Group A & 25 & 3.9 & 1.013 & $3-7$ & 0.564 \\
Group B & 27 & 4.1 & 1.357 & $3-8$ & \\
\hline
\end{tabular}

The difference in hemodynamic parameters between the two groups at 30 min after SBT was found to be statistically insignificant as depicted in Table 6.

The difference in ABG parameters between the two groups at 30 min time after SBT was found to be statistically insignificant as shown in Table 7.

Table 8 shows group B has $81.5 \%$ successful extubation as compared to group A (56\%) and the difference between the two groups was statistically significant $(\mathrm{P}<0.05)$.

The mean Scvo 2 at $1 \mathrm{~min}$ was $70.6 \%$ and at $30 \mathrm{~min}$ was $68.5 \%$ and the difference in $\mathrm{Scvo} 2$ at $1 \mathrm{~min}$ and $30 \mathrm{~min}$ was $2.1 \%$ which is statistically significant $(\mathrm{P}=0.043)$ as shown in Table 9a.

The difference in Scvo2 at $1 \mathrm{~min}$ and $30 \mathrm{~min}$ between the two groups is $5.54 \%$ which is statistically insignificant $(\mathrm{P}=5.54)$ as depicted in Table 9b.

Table 10 shows central venous oxygen saturation has a sensitivity of $95.4 \%$, specificity of $100 \%$, positive predictive value of $100 \%$, negative predictive value of $83.3 \%$, and diagnostic accuracy of $96.3 \%$.

\section{DISCUSSION}

Tolerating a SBT may indicate successful weaning, but it does not definitely predict extubation success. After

\begin{tabular}{|c|c|c|c|c|c|}
\hline \multirow[t]{2}{*}{ Parameter } & \multicolumn{2}{|c|}{ Group A } & \multicolumn{2}{|c|}{ Group B } & \multirow[t]{2}{*}{ P-value } \\
\hline & Mean & SD & Mean & SD & \\
\hline $\mathrm{SBP}(\mathrm{mmHg})$ & 138.4 & 13.36 & 142.04 & 13.76 & 0.339 \\
\hline $\mathrm{DBP}(\mathrm{mmHg})$ & 72.32 & 10.11 & 71.04 & 8.99 & 0.630 \\
\hline $\mathrm{MAP}(\mathrm{mmHg})$ & 94.44 & 8.07 & 94.70 & 8.59 & 0.910 \\
\hline $\begin{array}{l}\text { Respiratory rate } \\
\text { (breaths/min) }\end{array}$ & 20.64 & 4.07 & 20.89 & 2.36 & 0.787 \\
\hline
\end{tabular}

SBT: Spontaneous breathing trial

\begin{tabular}{|c|c|c|c|c|c|}
\hline \multirow[t]{2}{*}{ Parameter } & \multicolumn{2}{|c|}{ Group A } & \multicolumn{2}{|c|}{ Group B } & \multirow[t]{2}{*}{ P-value } \\
\hline & Mean & SD & Mean & SD & \\
\hline $\mathrm{pH}$ & 7.38 & 0.074 & 7.40 & 0.063 & 0.263 \\
\hline $\mathrm{pCO}_{2}$ & 37.32 & 4.670 & 38.07 & 4.367 & 0.550 \\
\hline $\mathrm{HCO}_{3}$ & 23.74 & 2.880 & 24.33 & 1.776 & 0.375 \\
\hline $\mathrm{Na}+{ }^{3}$ & 137.84 & 5.558 & 139.26 & 5.474 & 0.358 \\
\hline $\mathrm{K}+$ & 3.65 & 0.521 & 3.57 & 0.437 & 0.542 \\
\hline $\mathrm{Ca}+$ & 1.12 & 0.276 & 1.04 & 0.131 & 0.188 \\
\hline Lactate & 1.26 & 0.442 & 1.22 & 0.316 & 0.697 \\
\hline
\end{tabular}




\begin{tabular}{|c|c|c|}
\hline Parameter & Group A & Group B \\
\hline $\mathrm{SBP}(\mathrm{mmHg})$ & 138.92 & 143.56 \\
\hline $\mathrm{DBP}(\mathrm{mmHg})$ & 74.88 & 71.07 \\
\hline MAP $(\mathrm{mmHg})$ & 96.23 & 95.23 \\
\hline Respiratory rate (breaths/min) & 23.92 & 22.33 \\
\hline
\end{tabular}

\begin{tabular}{|c|c|c|c|c|c|}
\hline \multirow[t]{2}{*}{ Parameter } & \multicolumn{2}{|c|}{ Group A } & \multicolumn{2}{|c|}{ Group B } & \multirow[t]{2}{*}{ P-value } \\
\hline & Mean & SD & Mean & SD & \\
\hline $\mathrm{pH}$ & 7.40 & 0.166 & 7.39 & 0.071 & 0.706 \\
\hline $\mathrm{pCO}_{2}$ & 36.76 & 5.615 & 38.22 & 4.979 & 0.324 \\
\hline $\mathrm{HCO}_{3}^{2}$ & 23.12 & 2.804 & 23.22 & 2.292 & 0.890 \\
\hline $\mathrm{Na}+{ }^{3}$ & 138.80 & 4.752 & 140.70 & 4.639 & 0.150 \\
\hline $\mathrm{K}+$ & 3.67 & 0.454 & 3.83 & 0.550 & 0.267 \\
\hline $\mathrm{Ca}+$ & 1.21 & 0.443 & 1.23 & 0.318 & 0.878 \\
\hline Lactate & 1.28 & 0.390 & 1.27 & 0.345 & 0.889 \\
\hline
\end{tabular}

\begin{tabular}{|c|c|c|c|c|c|}
\hline \multirow[t]{2}{*}{ Extubation } & \multicolumn{2}{|c|}{ Group A } & \multicolumn{2}{|c|}{ Group B } & \multirow[t]{2}{*}{ P-value } \\
\hline & No. & \%age & No. & \%age & \\
\hline Successful & 14 & 56 & 22 & 81.5 & $0.046^{*}$ \\
\hline Failure & 11 & 44 & 5 & 18.5 & \\
\hline Total & 25 & 100 & 27 & 100 & \\
\hline
\end{tabular}

\begin{tabular}{|c|c|c|c|c|c|}
\hline ScvO2 & Mean & Range & $\begin{array}{l}\text { Change } \\
\text { in ScvO2 }\end{array}$ & SD & $P$ value \\
\hline $1 \mathrm{Min}$ & 70.6 & $60-81$ & 2.1 & 5.04 & 0.043 \\
\hline $30 \mathrm{Min}$ & 68.5 & 63-75 & & 2.79 & \\
\hline
\end{tabular}

\begin{tabular}{lccc}
$\begin{array}{l}\text { Table 9b: Group B with failed extubation (6 } \\
\text { patients) }\end{array}$ \\
\hline ScvO2 & Mean & Range & Change in Scv02 \\
\hline 1 Min & 69 & $66-71$ & 5.54 \\
30 Min & 63.16 & $61-64$ & \\
\hline
\end{tabular}

a successful SBT, the rate of EF within the following 2-3 days may reach up to $30 \%$ of the patients.

In this prospective, clinical study we established that $\mathrm{ScvO} 2$ as an additional to conventional criteria's can predict the outcome of extubation, with the chance of EF increasing substantially with decrease of ScvO2 more than 3.8 from its baseline value at the start of SBT.

\begin{tabular}{|c|c|c|}
\hline Parameter ScvO2 & Value (\%) & $95 \% \mathrm{Cl}$ \\
\hline Optimal cutoff & $\geq 70$ & \\
\hline Sensitivity & 95.4 & $78.2-99.1$ \\
\hline Specificity & 100 & $56.6-100$ \\
\hline PPV & 100 & $84.5-100$ \\
\hline NPV & 83.3 & $43.7-96.9$ \\
\hline Accuracy & 96.3 & 81.7-99.3 \\
\hline Area under the ROC curve & 0.986 & $0.847-0.998$ \\
\hline
\end{tabular}

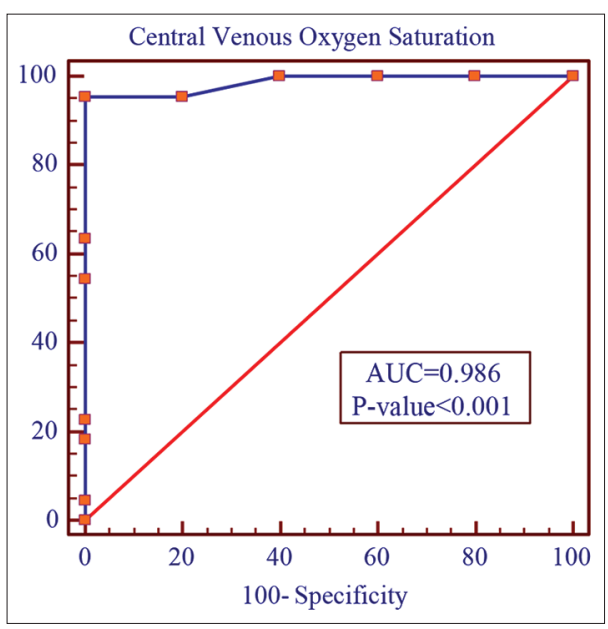

Corresponding to weaning guidelines, the outcome of SBT depends on a set of different variables and characteristics evaluated upon the termination of the $30 \mathrm{~min}$ trial. While measuring ScvO2 value is not currently considered among these criteria this study establishes the immense role of $\Delta \mathrm{ScvO} 2$ as an additional factor that has an ability to predict weaning outcome with diagnostic accuracy superior to that of tolerance to SBT alone.

The patients throughout this study were weaned using a two-step protocol, wherein $18.5 \%$ of patients had an extubation failure. Cason CL et al. ${ }^{13}$ indicated that SCVO2 was an important predictor of weaning failure, since weaning failure was associated with a drop SCVO2 of over $60 \%$. $\triangle \mathrm{SCVO} 2$ was found to be single predictor that predicted failed weaning in additional to the conventional criteria. Our results showed that the mean difference in SCVO2 in the group of patients who failed extubation was distinctly more than that of patients with successful extubation with $\triangle \mathrm{SCVO} 2$ having high predictive value for extubation failure reaching $91 \%$.

In an attempt to understand the effect of cardiac problems on the weaning process an interesting study performed by Jubran A et al., ${ }^{14}$ demonstrated an elevation in the cardiac index value at the termination of SBT in the successful extubation cluster compared with a nonsignificant change 
in the cardiac index value within the failed extubation cluster.

No significant difference was found between the both groups considering different laboratory tests. The same was found with regard to vital signs, wherein there was no difference in both groups at the beginning and at the end of SBT. These results were similar to those of the study carried out by Ayman T and Khalid $\mathrm{MI}^{15}$ wherein these reported the absence of any statistically significant variance among both clusters considering clinical features or demographic data (age, sex, in addition to vital signs).

Saugel B et al., ${ }^{16}$ showed similar results in a cohort study consisting of 61 patients, as they also confirmed the absence of any considerable distinction between patients with successful or failed extubation considering the age, sex, or vital signs, although Savi A et al., ${ }^{17}$ in a cohort study consisting of 500 patients singled out age a significant variant. This might be explained by the variation in population groups and different reasons for mechanical ventilation addressed in these studies. Our results reported no distinction among both clusters of patients in all central venous blood gases reading at the beginning of 30-min trial. However, as regard the termination of SBT, patients with successful extubation had significantly higher $\mathrm{ScrO} 2$, $\mathrm{pH}$, base excess, and oxygen saturation compared with a significantly higher $\mathrm{pCo}_{2}$ in the failed extubation group.

Mokhlesi B et al., ${ }^{18}$ also found that hypercapnia before extubation significantly increases the chances of weaning failure and is mainly caused by lack of balance between workload and strength of respiratory muscles.

$\Delta \mathrm{ScvO} 2$ was found to be single predictor that predicted failed weaning in additional to the conventional criteria. Our results showed that the mean difference in $\mathrm{ScvO} 2$ in the group of patients who failed extubation was distinctly more than that of patients with successful extubation, with $\Delta \mathrm{ScvO} 2$ having high predictive value for $\mathrm{EF}$ reaching $91 \%$.

A similar study by Tiexeira $\mathrm{C}$ et al., ${ }^{4}$ showed that before SBT the $\Delta \mathrm{ScvO} 2$ was not different between both groups, but the reduction of $\mathrm{ScvO} 2$ during T-tube trial had the ability to predict $\mathrm{EF}$ in $86 \%$ of cases, while the $\mathrm{ScvO} 2$ remained unchanged in the extubation success group. According to our study in which 52 patients with different comorbidities were admitted to ICU were studied. Two groups were made, group A and group B among these groups along with the conventional criteria for extubation, the group $\mathrm{B}$ was supported with $\mathrm{ScrO} 2$ criteria and it was seen that group B patients had much lower chances of reintubation. Since other parameters did not differ too much among the two groups. The central venous oxygen saturation has significantly improved the successful extubation outcome. As per the statistical analysis, the $\mathrm{p}$ value holds significance in all parameters.

In the previous studies Jubran A et al., ${ }^{14}(1998)$ utilized Svo2, monitoring in order to assess cardiovascular performance and global tissue oxygenation during the weaning process. In this study the group of patients who failed weaning established a progressive decrease in $\mathrm{ScvO} 2$ values, compared to the rest, probably reflecting the increased O2ER of respiratory muscles.

\section{Limitations of the study}

None.

\section{CONCLUSION}

Our study concluded that in successfully extubated group of patients tolerating SBT, the $\mathrm{ScvO} 2$ at $30 \mathrm{~min}$ did not fall by more than $4 \%$ of the value at $1^{\text {st }}$ min of SBT. There was a mean difference of $2 \%$ fall in $\mathrm{ScvO} 2$ after SBT in our group of patients. So, we concluded that the $\mathrm{ScvO} 2$ criteria when added to conventional criteria help the clinician to estimate proper time for extubation and reduce the rates of reintubation. The previous studies also have revealed that fall in $\mathrm{ScrO} 2$ by more than $4 \%$ from baseline values at 30 min of SBT have higher chances of extubation failure.

\section{ACKNOWLEDGMENT}

The authors take this opportunity to thank the department of Anaesthesiology and Critical Care, Government Medical College, Srinagar for their whole hearted support.

\section{REFERENCES}

1. Asteban A, Ferguson ND, Maedemo, Frusto-Vivar F, Apezteguia C, Bocharc L, et al. Evolitoom of mechanical ventilation I response to clinical research. Am J Respir Crit Care Med. 2008; 177(2): 170-177. https://doi.org/10.1164/ rccm.200706-8930C

2. Boles JM, Bion J, Connors A, Herridg M, Marsh B, Melot C, et al. weaning from mechanical ventilation. Eur Respir J. 2007;29(5):1033-1056.

https://doi.org/10.1183/09031936.00010206

3. Macintyre NR, Cook DJ, Ely EW Jr., Epstein SK, Fink JB, Heffner JE, et al. Evidence-based guidelines for weaning and discontinuing ventilatory support: A collective task force facilitated by the American college of chest physicians; the American association for respiratory care; and the American college of critical care medicine. Chest. 2001;120(6):3755-3955. https://doi.org/10.1378/chest.120.6_suppl.375S

4. Teixeira C, D Silva NB, Savi et al. Central venous saturation is a predictor of reintubation in difficult-to-wean patients. Critical Care Med. 2010;38(2):491-496.

https://doi.org/10.1097/CCM.0b013e3181bc81ec 
5. Estaban A, Frutos F, Tobin MJ, Alía I, Solsona JF, Valverdú I, Fernández $R$, et al. A comparison of four methods of weaning patients from mechanical ventilation. Spanish lung failure collaborative group. N Engl J Med. 1995;332(6):345-350. https://doi.org/10.1056/NEJM199502093320601

6. Torres A, Serra-Batlles J, Ros E, Piera C, de la Bellacasa JP, Cobos A, et al. Pulmonary aspiration of gastric contents in patients receiving mechanical ventilation: The effect of body position. Ann Intern Med. 1992;116(7):540-543. https://doi.org/10.7326/0003-4819-116-7-540

7. Estaban A, Alia I, Tobin MJ, Gil A, Gordo F, Vallverdú I, et al. Effect of spontaneous breathing trial duration on outcome of attempts to discontinue mechanical ventilation. Spanish Lung Failure Collaborative Group. Am J Respir Crit Care Med. 1999;159(2):512-518. https://doi.org/10.1164/ ajrccm.159.2.9803106

8. Vallverdo I, Calef $N$, Subirana $M$, Net A, Benito $S$ and Mancebo J. Clinical characteristics, respiratory functional parameters, and outcome of a two-hour T-piece trial in patients weaning from mechanical ventilation. Am J Respir Crit Care Med1998;158(6):1855-1862. https://doi.org/10.1164/ ajrccm.158.6.9712135

9. Lee KH, Hui KP, Chan TB, Tan WC and Lim TK. Rapid shallow breathing (frequency-tidal volume ratio) did not predict extubation outcome. Chest. 1994;105(2):540-543.

https://doi.org/10.1378/chest.105.2.540

10. Meady MO, Guyatt G, Cook D, Griffith L, Sinuff T, Kergl C, et al. Predicting success in weaning from mechanical ventilation. Chest. 2001;120 Suppl 6:400s-424s.

https://doi.org/10.1378/chest.120.6_suppl.400S

11. Conti G, Montini L, Penniksi MA, Cavaliere F, Arcangeli A, Bocci MG, et al. A prospective, blinded evaluation of indexes proposed to predict weaning from mechanical ventilation. Intensive Care Med. 2004;30(5):830-838.

https://doi.org/10.1007/s00134-004-2230-8.

12. Samiha S. Ashmawi, Hala M. Salem, Muhammad E. Nagy. Central venous oxygen saturation as a predictor of failure of weaning from mechanical ventilation. Egyptian $\mathrm{J}$ of Chest Diseases and Tuberculosis. 2020; 69: 155-161.

13. Cason CL, DeSalvo SK and Ray WT. Changes in oxygen saturation during weaning from short-term ventilator support after coronary artery bypass graft surgery. Heart Lung. 1994;23(5):368-375.

14. Jubran A, Mathru M, Dries D and Tobin MJ. Continuous recordings of mixed venous oxygen saturation during weaning from mechanical ventilation and the ramifications thereof. Am J Respir Crit Care Med. 1998;158(6):1763-1769. https://doi.org/10.1164/ajrccm.158.6.9804056

15. Ayman $\mathrm{T}$ and Khalid MI. Central venous oxygen saturation as a predictor of extubation failure in mechanically ventilated chronic obstructive pulmonary disease patients. J Am Sci. 2014;10:6.

16. Saugel B, Rakett P, Hapfelneier A, Schulthesis C, Phillip B, Thies $\mathrm{P}$, et al. Prediction of extubation failure in medical intensive care unit patients. J Crit Care. 2012;27(6):571-577. https://doi. org/10.1016/j.jcrc.2012.01.010

17. Savi A, Teixeira C, Silva JM, Borges LG, Pereira PA, Pinto KB, et al. Weaning predictors do not predict extubation failure in simple-to-wean patients. J Crit Care. 2012;27(2):221.e1-221.e8. https://doi.org/10.1016/j.jcrc.2011.07.079

18. Mokhlesi B, Tulaimat A, Gluckman TJ, Wang Y, Evans AT and Corbridge TC. Predicting extubation failure after successful completion of a spontaneous breathing trial. Respir Care. 2007;52(12):1710-1717.

\section{Authors Contribution:}

IAB-Concept and design of study, prepared first draft of manuscript and stastical analysis; FB- Concept coordination, and preparation of manuscript; JIN- Review of literature and preparation of manuscript; MSM- Interpreted the results and reviewed the literature

\section{Work attributed to:}

Intensive care units, Department of Anesthesiology and Critical Care, Goverment Medical College, Srinagar, Jammu and Kashmir, India

\section{Orcid ID:}

Dr. Imtiaz Ahmad Bhat - (i) https://orcid.org/0000-0002-0785-045X

Dr. Farhana Bashir - (i) https://orcid.org/0000-0003-3180-2367

Dr. Javed Iqbal Naqeshbandi - (1) https://orcid.org/0000-0001-9242-6647

Dr. Mohammad Sadiq Malla - (1) https://orcid.org/0000-0003-2189-6320

Source of Support: Nil, Conflict of Interest: None declared. 